\title{
126. A Note on the Structure and Function of the Anterior Region of the Alimentary Canal of the Larval and Adult Molge vulgaris.
}

\author{
By Yaichirô OKADA. \\ Zoological Institute, Tokyo Higher Normal School.
}

(Comm. by A. OKA, M.I.A., Oct. 12, 1933.)

It is well known that the food of most larvel amphibia consists of small plants whereas the adults are generally exclusively carnivorous. Few observations, however, appear to have been made on the comparative histology and physiology of the alimentary canal of the adult and the larva.

The material, Molge vulgaris, upon which the following observations were based was collected from a small pond near the Fresh-water Biological Station on Lake Windermere in October 1932 and was examined during my stay at the Zoology Department of the University of Edinburgh. I am indebted to Prof. J. H. Ashworth F. R. S. for his courtesy in affording me facilities and accommodation in his Department, and to Dr. Craig-Bennett for assistance and suggestions in connection with the experimental observations.

Three stages have been examined, the adult, the young (that is to say the larva directly after the loss of the external gills) and the fullygilled larva. For histological examination Helly's Formol Zenker was used as a fixative and sections were stained with Heidenhain's haematoxylin counterstained with Masson's modification of Mallory's stain. The hydrogen-ion concentration of the different regions of the alimentary canal was determined by Clark and Lub's spot method. In the case of small specimens a small quantity of glass-distilled water was added to increase the size of the spot. The enzyme extracts were prepared by splitting open the alimentary canal, rapidly washing out any food, scraping the mucous membrane lightly and mixing the scrapings with $0.9 \%$ Sodium Chloride and 30\% alcohol. Owing to the small amount of material which could be obtained in this manner the extracts were used only for qualitative experiments. The enzymes were detected by the usual method, incubation at $30^{\circ} \mathrm{C}$. Controls were made to each experiment.

The anterior part of the alimentary canal as far back as the pyloric sphincter is characterised by a very slight development of 
muscle. The oesophagus is lined by a ciliated mucous membrane and there are many gland cells in the submucuosa, arranged in the form of compound glands. There is little difference histologically between the oesophagus of the larva, young and adult. The $\mathrm{PH}$ of the oesophagus does not appear to vary with feeding and in each stage of development examined had the value of PH 7.2-7.4. Extracts of the oesophagus showed the presence of an amylolytic enzyme causing rapid digestion of starch at $\mathrm{PH}$ 7.2. The digestion, however was rapidly inhibited, (or the enzyme destroyed) at a $\mathrm{PH}$ of 4.0. No other enzymes could be detected in the oesophagus.

Histologically the stomach is divisable into two regions, an anterior and a posterior. The anterior (cardiac) stomach has no serous coat but the mucous membrane is ciliated, these cilia being continuous with that of the oesophagus. Further the mucous membrane is in the form of five longitudinal ridges. In the cardiac stomach of the adult there are many simple gastric glands, with proximal oxyntic cells and distral peptic cells. The structure in the young is essentially similar but in the larva there are no oxyntic cells and only a few peptic cells. These peptic cells in the anterior part of the stomach of the larva are below the epithelium and are not yet in connection with the lumen of the alimentary canal and clearly appear to be developing.

The pyloric part of the stomach is characterised by a serous coat and by the absence of cilia on the mucous membrane. In the adult the gastric glands are abundant. In the young

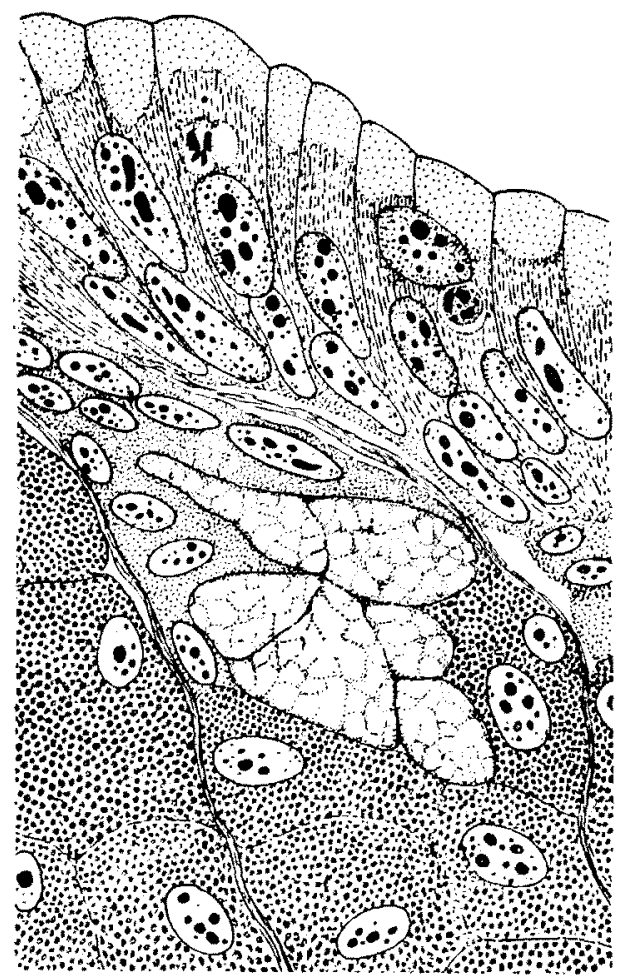

Fig. 1. Transverse Section of the stomach of adult Molge vulgaris. ca. $\times 950$. the peptic cells are well developed but the oxyntic cells are few in number and are probably developing. In the larva, while the peptic cells are moderately common, few appear to have attained access to the lumen of the stomach.

It was found impossible to separate the anterior and posterior parts of the stomach for the purpose of observing the $\mathrm{PH}$ and pre- 
No. 8.] A Note on the Structure and Function of the Anterior Region.

paring enzyme extracts. (The total length of the stomach of the larva is $5 \mathrm{~mm}$.) During starvation the $\mathrm{PH}$ of the stomach of the adult was 7.8, that of the young and the larva during starvation was substantially the same. After feeding, however, the PH of the stomach of the adult dropped to 5.6, whereas that of the larva remained at the value 7.6-7.8.

The extract of the stomach of the adult contained a proteolytic enzyme, giving digestion of an acid solution of casein. Incubating at a temperature of $30^{\circ} \mathrm{C}$. the $\mathrm{PH}$ optimum for this enzyme, as indicated by Socenson's formol titration, was about 2.4. A PH as low as this was never found by the spot method in the stomach after feeding. However the effect of dilution of the stomach contents with water will have the effect of raising the $\mathrm{PH}$, which may account for the discrepancy. On the other hand it is possible that the $\mathrm{PH}$ optimum varies with temperature.

The extract of the stomach of

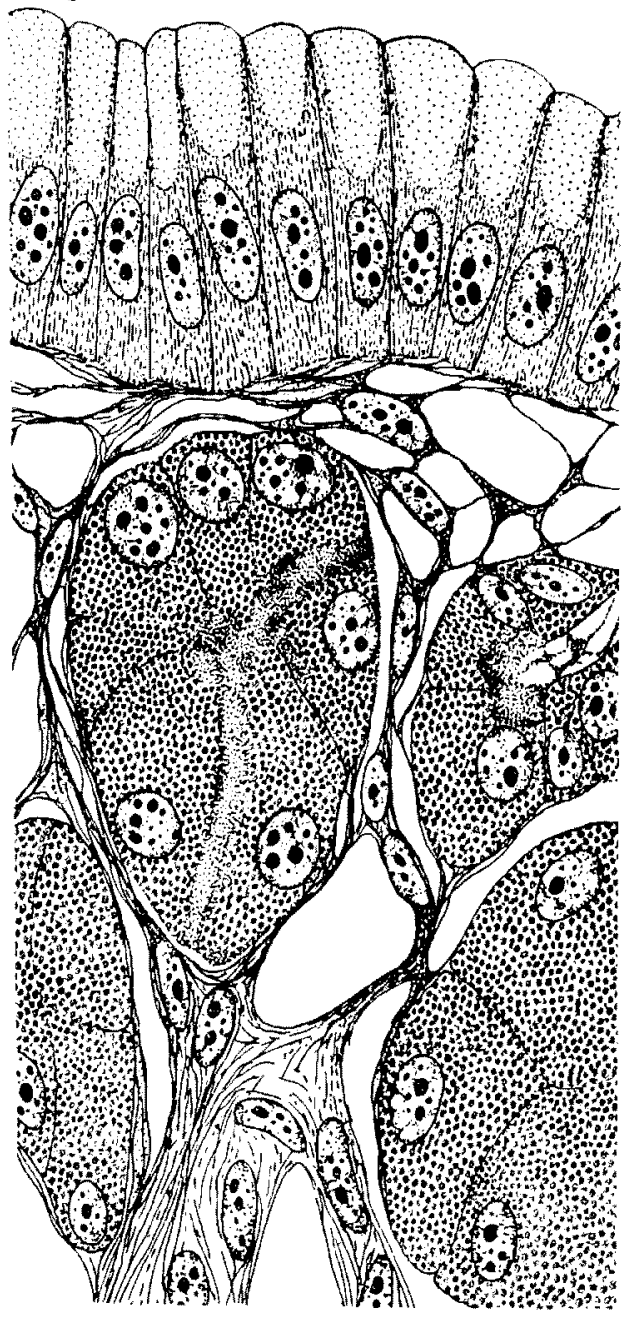

Fig. 2. Transverse section of the stomach of larva Molge vulgaris. ca. $\times 950$. the larva contained no detectable proteolytic enzyme.

The pyloric sphincter is equally well developed in the larva and in adult.

It is clear that in the larval Molge vulgaris there is no peptic digestion in the stomach, the stomach is therefore functionally comparable with the stomach of such Teleosts as Fundulus heteroclitus (Babkin and Bowie, 1928). On the other hand the pepsin -hydrochloric acid system does not appear to be replaced by a proteolytic enzyme acting near neutrality, as exists in Zoarces anguillaris (Mac Kay 1929).

Additional experiments indicate that the distribution of amylolytic, proteolytic and lipolytic enzymes in the adult Molge vulgaris appears to be essentially similar to that found in a mammal. Owing to the very small size of the digestive organs it was not possible to investigate 
the distribution of enzymes in the larva, and it is not known whether there is any difference in the protein digestion in the duodenum of the larva and the adult. The young animals examined showed clearly that the peptic system in the stomach is developed after the loss of the external gills, at a time when the animal chages its diet.

The powerful amylolytic enzyme of the oesophagus is interesting, the slight development of muscle in the wall of the anterior part of the alimentary canal and the comparatively weak jaws of the newt. Further the adverse influence of a low $\mathrm{PH}$ on the digestion by this enzyme suggests that digestion takes place in two stages, that the cardiac part of the stomach is functionally different from the pyloric part, as well as histologically distinct.

\section{Reference.}

Babkin, B. P. \& Bourie, D. J. : Biol. Bull., 54, p. 254, 1928.

— : Biol. Bull., 57, p. 272, 1929.

Bensley, R. R.: Biol. Bull., 11, pp. 87-104, 1900.

Blacher, L. J.: Biol. Zentrabl., pp. 271-284, 285-292, 1930.

Bodansky, M. \& Rose, W. C.: Amer. Journ. Phys., 62, p. 482, 1922.

Carlier, E. W.: La Cellule, 16, 1899.

Dawes, B.: Journ. Mar. Biol. Ass. 17, 1930.

Goldsmith, J. B. : Trans. Amer. Mic. Soc., 48, pp. 292-301, 1929.

Kingsbury, B. F. : Proc. Amer. Micr. Soc., 16, pp. 19-65, 1894.

Langlen, J. N. : Phil. Trans. Roy. Soc., 172, 1881.

Müller, H. : Arch. Ges. Physiol., 192, pp. 214-224, 1922.

Noble, G. K.: The Biology of the Amphibia., pp. 201-211, 1931.

Ross, M. J.: Biol. Bull., 4, No. 2, 1902.

Sullivan, M. : Bull. Bur. Fish. Wash., 27, pp. 1-32, 1907.

Vonk, H. J. : Zeit. Vergl. Pay., 5, p. 445, 1927.

Yonge, C. M. : Sci. Rept. Barrier Reef Exp., 1, p. 59, 1930.

- : Conseil Perm. Int. l'Expl. Mer., 6, No. 1, pp. 175-212, 1931. 